\title{
Several Extracellular Domains of the Neural Cell Adhesion Molecule L1 Are Involved in Neurite Outgrowth and Cell Body Adhesion
}

\author{
Frank Appel, Jürgen Holm, Jean-François Conscience, and Melitta Schachner \\ Department of Neurobiology, Swiss Federal Institute of Technology, Hönggerberg, 8093 Zürich, Switzerland
}

\begin{abstract}
The neural cell adhesion molecule L1 is a multidomain protein that plays important roles in cell adhesion, migration, and neurite outgrowth. To analyze structure-function relationships of $L 1$ in neurite outgrowth and cell body adhesion, we have expressed and purified a set of different fragments of the extracellular part of this glycoprotein in $\mathrm{CHO}$ cells and in Escherichia coli. When neurite outgrowth from small cerebellar neurons was measured on substrate-coated L1 or L1 fragments, neurite outgrowth was promoted by the immunoglobulin-like domains I-II, III-IV, and V-VI, and by the fibronectin type III homologous repeats 1-2, while the fibronectin type III homologous repeats 3-5 were ineffective. In contrast, cell bodies of small cerebellar neurons adhered mostly to the immunoglobulin-like domains I-II and V-VI, and to the fibronectin type III homologous repeats $3-5$, but less to the immunoglobulin-like domains III-IV and fibronectin type III homologous repeats 1-2. In both assays, the neuronal cell surface receptor for all active protein fragments was identified as L1. No significant differences in functional activities were found between fragments with and without carbohydrate structures. These findings indicate that $L 1$ uses several domains for homophilic interactions overlapping for the two functions analyzed here, but also showing some regional specialization. Furthermore, we show that a homophilic molecule uses several domains in one function, with neurite outgrowth requiring more domains than adhesion for maximal activity.
\end{abstract}

[Key words: cell adhesion, fibronectin type III homologous repeats, homophilic binding, immunoglobulin superfamily, $[1$, neurite outgrowth]

Cell-to-cell interactions have been developed to a high degree of precision in the nervous system. Various cell surface and extracellular matrix molecules have been identified to be involved in neuron-neuron and neuron-glia recognition (for reviews, see Dodd and Jessell, 1988; Edelman et al., 1990; Edelman and Crossin, 1991; Schachner, 1991). In search for their particular functions, their structure was determined with the aim of relating specific functional traits to distinct structural

\footnotetext{
Received Jan. 14, 1993; revised May 11, 1993; May 17, 1993.

We are grateful to Dr. Sergio Gloor, Department of Neurobiology, ETH Zürich, and Dr. Johannes Buchner, University of Regensburg, for helpful suggestions; Dr. Thomas Jessell, Columbia University, New York, for TAG-1 antibodies; Dr. James Cohen, Guy's Hospital, London, and Dr. Joanne Taylor, Department of Neurobiology, ETH Zürich, for critical reading of the manuscript; Jürg Sigrist for technical assistance; Anja Marxer for the preparation of brain $\mathrm{Ll}$ and brain MAG; and Studienstiftung des Deutschen Volkes for a predoctoral fellowship (F.A.). This work was supported by the Schweizerischer Nationalfonds.

Correspondence should be addressed to Melitta Schachner at the above address.

Copyright (C) 1993 Society for Neuroscience $0270-6474 / 93 / 134764-12 \$ 05.00 / 0$
}

features. Several neural cell adhesion molecules were shown to belong to the immunoglobulin superfamily (Williams and Barclay, 1988) and to contain structural motifs characteristic of extracellular matrix molecules, the fibronectin type III homologous repeats. These include N-CAM (Barthels et al., 1987; Cunningham et al., 1987), L1 (Moos et al., 1988), Ng-CAM (Burgoon et al., 1991; Grumet, 1992), Nr-CAM (Grumet et al., 1991), TAG-1 (axonin-1) (Furley et al., 1990; Zuellig et al., 1992), and F3/F1 1 (Brümmcndorf et al., 1989; Gennarini et al., 1989) in vertebrates, and their homologs in invertebrates (Harrelson and Goodman, 1988; Mayford et al., 1992).

The neural cell adhesion molecule L1, and its homologs in other species, such as human L1CAM and rat NILE, is one of these molecules (for reviews, see Schachner, 1990, 1991). The extracellular part of $\mathrm{L} 1$ consists of six immunoglobulin-like domains of the C2 type (Williams and Barclay, 1988) and five fibronectin type III homologous repeats. L1 contains a membrane-spanning region and a short, highly conserved cytoplasmic tail of approximately 120 amino acids (Moos et al., 1988). $\mathrm{L} 1$ increases neurite outgrowth on $\mathrm{L} 1$-positive partner cells (Bixby et al., 1987; Chang et al., 1987; Seilheimer and Schachner, 1988) or on purified L1 (Lagenaur and Lemmon, 1987; Chang et al., 1990) and is a substrate for cell body adhesion (Kadmon et al., 1990a; Miura et al., 1992). It has been suggested that ncurite outgrowth on substratc-coated L/l and ccll adhesion to L1 are due to a homophilic binding mechanism (Lemmon et al., 1989; Miura et al., 1992). In addition to this homophilic interaction, evidence for assisted homophilic (Kadmon et al., $1990 \mathrm{a}, \mathrm{b})$ and heterophilic binding mechanisms has been provided (Grumet and Edelman, 1988; Werz and Schachner, 1988; Drazba and Lemmon, 1990; Pollerberg et al., 1990; Smith et al., 1990; Kuhn et al., 1991). Furthermore, L1 is involved in signal transduction from the cell surface to the interior, leading to changes in the levels of intracellular second messengers, such as inositol phosphates, $\mathrm{Ca}^{2+}, \mathrm{pH}$, and cyclic nucleotides (Schuch et al., 1989; von Bohlen und Halbach et al., 1992; Williams et al., 1992), and in kinase activity (Sadoul et al., 1990; Atashi et al., 1992).

In contrast to cell surface molecules of the immune system, structure-function relationships of the neural cell surface molecules belonging to the immunoglobulin superfamily remain largely unresolved. Apart from studies on N-CAM (Frelinger and Rutishauser, 1986; Frei et al., 1992; Rao et al., 1992), little attention has been given to the involvement of the immunoglobulin-like domains and fibronectin type III homologous repeats of different neural cell adhesion molecules in such functions as adhesion of neuronal cell bodies and neurite outgrowth. To investigate such structure-function relationships in L1 and to compare them to those of N-CAM, we produced recombinant 
glycoprotein and protein fragments in Chinese hamster ovary (CHO) cells and Escherichia coli and used these as substrates for neuronal cell body adhesion and neurite outgrowth. Here we report that immunoglobulin-like domains, as well as tibronectin type III homologous repeats, are involved in $\mathrm{L} 1$-mediated adhesion and neurite outgrowth. We could show that at least four domains promote neurite outgrowth and at least five domains participate in short-term adhesion. As demonstrated by antibody inhibition experiments, $\mathrm{Ll}$ is a part of the cellular receptor for all active $L 1$ protein fragments mediating neuronal adhesion and neurite outgrowth.

\section{Materials and Methods}

\section{Materials}

L1 (brain L1) and the myelin-associated glycoprotein (brain MAG) were purified by immunoaffinity chromatography from detergent-containing extracts of crude membrane fractions of adult mouse brain using monoclonal antibody columns (Rathjen and Schachner, 1984; Poltorak et al., 1987). Laminin from the murine EHS sarcoma was obtained from Boehringer Mannheim (Mannheim, Germany). Poly-L-lysine and fatty acidfree bovine serum albumin were from Sigma (München, Germany).

The rat monoclonal antibodies against L1 (324, 555, and 557.B6) were used as ammonium sulfate precipitates of hybridoma culture supernatants containing $1 \%$ fetal bovine serum, and were dissolved in and dialyzed against phosphate-buffered saline, pH 7.3 (PBS), before use. They will be described in a forthcoming report (F. Appel, J.-F. Conscience, J. Holm, F. von Bohlen und Halbach, A. Faissner, and M. Schachner, unpublished observations). Monoclonal antibody 324 reacts, according to ELISA, with the recombinant protein containing the immunoglobulin-like domains I-VI. Monoclonal antibodies 555 and 557.B6 react, in ELISA, with an epitope at the border between the fibronectin type III homologous repeats 2 and 3 . Polyclonal antibodies against L1 were obtained from rabbits immunized with brain Ll (Rathjen and Schachner, 1984). The IgG fractions of these antibodies were purified by chromatography using a protein A Sepharose 4B fast-flow column (Sigma, München, Germany) (Ey et al., 1978). For immunoaffinity purification of polyclonal L1 antibodies, the ammonium sulfate-precipitated fraction was bound to an L1-coupled Sepharose CL4B column and eluted as described previously (Martini and Schachner, 1986). All secondary antibodies were obtaincd from Dianova (Hamburg, Germany). Monoclonal antibody columns containing Sepharose CL4B beads conjugated with antibodies 324 or 555 were prepared according to standard procedures (Harlow and Lane, 1988).

\section{Analytical procedures}

Protein determinations were performed as described by Bradford (1976). Proteins were separated by SDS-PAGE on $8 \%, 10 \%$, or $12 \%$ slab gels (Laemmli, 1970), under reducing or nonreducing conditions. Protein bands were stained with Coomassie blue $(0.05 \%$ Coomassie brilliant blue R250, $50 \%$ methanol, $10 \%$ acetic acid) or transferred to nitrocellulose filters (0.45 $\mu \mathrm{m}, \mathrm{BA} 85$; Schleicher and Schuell, Dassel, Germany) for Western blot analysis according to Faissner et al. (1985), using alkaline phosphatase-coupled secondary anti-rabbit or anti-rat IgG. Polyclonal and monoclonal antibodies to $\mathrm{L} 1$ were used at concentrations of $0.5 \mu \mathrm{g} / \mathrm{ml}$ and $50 \mu \mathrm{g} / \mathrm{ml}$, respectively.

The ELISAs were performed as described by Husmann et al. (1992) using polyclonal and monoclonal antibodies at concentrations of 0.5 $\mu \mathrm{g} / \mathrm{ml}$ and $100 \mu \mathrm{g} / \mathrm{ml}$, respectively. Secondary antibodies were horseradish peroxidase-coupled anti-rabbit or anti-rat $\mathrm{IgG}$ and developed

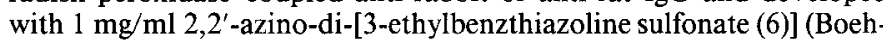
ringer Mannheim, Mannheim, Germany) dissolved in $100 \mathrm{~mm} \mathrm{Na-}$ acetate, $50 \mathrm{~mm}$ Na-phosphate ( $\mathrm{pH} 4.2$ ), and $0.01 \% \mathrm{H}_{2} \mathrm{O}_{2}$. The optical density was measured at $405 \mathrm{~nm}$ with an ELISA reader (Titertek Multiskan MKII, Flow, Basel, Switzerland).

To estimate the coating efficiency of proteins on bacteriological plasticware, 96-well plates (2-69620A, Nunc, Denmark) were coated with proteins or glycoproteins at concentrations from 0.5 to $30 \mu \mathrm{g} / \mathrm{ml}$ for 3 $\mathrm{hr}$ at $37^{\circ} \mathrm{C}$ in PBS. Then, the plates were washed once with PBS, incubated with a Coomassie brilliant blue solution $(0.05 \%$ Coomassie brilliant blue R250, 50\% methanol, $10 \%$ acetic acid) for $30 \mathrm{~min}$ at room temperature and washed thoroughly with distilled water. Bound Coom- assie blue was solubilized first with $20 \mu \mathrm{l}$ of $10 \%$ SDS in $\mathrm{H}_{2} \mathrm{O}(10 \mathrm{~min})$ and then with $50 \mu \mathrm{l}$ of $70 \%$ ethanol (30 min), all at room temperature. The optical density of the Coomassie blue solution was determined at $595 \mathrm{~nm}$ using an ELISA reader. To estimate the coating efficiency of proteins on poly-L-lysine-coated glass coverslips, the same procedure was used, but the bound Coomassie blue was solubilized with $150 \mu 1$ of $10 \% \operatorname{SDS}$ in $\mathrm{H}_{2} \mathrm{O}$ and $50 \mu \mathrm{l}$ of $70 \%$ ethanol.

\section{Recombinant protein expression in $\mathrm{CHO}$ cells}

To generate plasmids containing secretion signal sequences and stop codons in the right frame, different strategies were used. For the sequences coding for the complete extracellular part of L1 (sL1CHO, amino acids 1-1093 according to Moos et al., 1988) and for the six immunoglobulin-like domains (IgI-VICHO, amino acids 1-631), an oligonucleotide coding for three stop codons in every reading frame (CTAGCTAGCTAG) was ligated into the blunt-ended EcoNI [base pair (bp) 3274, sL1CHO] or ApaLI (bp 1888, IgI-VICHO) restriction site (Fig. 1A). For the fibronectin type III homologous repeats, a plasmid was constructed that encoded the signal peptide of L1 (amino acids 120), the first 10 amino acids of $\mathrm{Ll}$ (amino acids 21-30), three extra amino acids resulting from the addition of a BglII linker, the coding sequence of amino acids 631-1093 flanked by a BamHI linker (Boehringer Mannheim, Mannheim, Germany), and stop codons in all three reading frames (F. Appel, J. Holm, and S. Gloor, unpublished observations). The correct sequence of the three plasmids was confirmed by sequencing both ends. The coding sequences of the three constructs were isolated and inserted into the pEE. 14 eukaryotic expression vector, which carries the human cytomegalovirus promotor and a glutamine synthetase gene as selection marker (Crocket et al., 1990; Bebbington, 1991).

Transfection with these constructs and selection of transfected $\mathrm{CHO}$ cells were carried out according to Bebbington (1991). In brief, semiconfluent $\mathrm{CHO}$ cells were transfected using the calcium phosphate precipitation method and transfected cells were selected in glutamate-free medium (GIBCO/Bethesda Research Labs, Basel, Switzerland) containing $10 \%$ dialyzed fetal calf serum and $25 \mu \mathrm{M} \mathrm{L}$-methionine sulfoximine. After 2 weeks, colonies were isolated and expanded in the same medium. Supernatants of confluent cultures were collected and subjected to ELISA and Western blot analysis. Typically, 5 out of $30 \mathrm{col}-$ onies secreted the protein in detectable amounts and the best producers were cloned. The conditioned medium of these clones was used to isolate the recombinant proteins.

\section{Recombinant protein expression in E. coli}

DNA fragments encoding seven different portions of $\mathrm{L} 1$ were produced using appropriate restriction enzymes (Fig. $1 B$ ), namely, fragments coding for the immunoglobulin-like domains I-VI (IgI-VIEco, amino acids 44-661 of L1 according to Moos et al., 1988), I-II (IgI-IIEco, amino acids 22-240), III - IV (IgIII-IVEco, amino acids 239-427), and V-VI (IgV-VIEco, amino acids 426-661), and the fibronectin type III homologous repeats $1-5$ (FN1-5Eco, amino acids 631-1093), 1-2 (FN12Eco, amino acids $631-826$ ), and 3-5 (FN3-5Eco, amino acids 8281093). Each fragment was subcloned in the unique BamHI restriction site of the pET vector (Studier and Moffatt, 1986; Rosenberg et al., 1987; Studier et al., 1990) or modified pET vector (J. Holm, F. Appel, and $S$. Gloor, unpublished observations) by treating all fragments with T4 DNA polymerase and adding BamHI linkers at both ends according to standard methods (Sambrook et al., 1989). The correct sequence of the plasmids was confirmed by sequencing with a $T 7$ polymerase sequencing kit (Pharmacia, Uppsala, Sweden). Finally, the $E$. coli strain BL21 (DE3) was transformed with the plasmids (Studier and Moffatt, 1986).

For production of recombinant protein, transformed $E$. coli cells were grown at $37^{\circ} \mathrm{C}$ in $1000 \mathrm{ml}$ Erlenmeyer flasks containing $250 \mathrm{ml}$ of LB medium with $200 \mu \mathrm{g} / \mathrm{ml}$ ampicillin. Protein synthesis was induced by adding $0.4 \mathrm{~mm}$ isopropyl- $\beta$-D-1-thiogalactopyranoside to cultures in exponential phase $\left(\mathrm{OD}_{600}\right.$ between 0.6 and 0.8$)$. The induced proteins were isolated as inclusion bodies by sonifying the harvested cells for $3 \mathrm{~min}$ in $10 \mathrm{ml}$ of PBS on ice. Inclusion bodies collected by centrifugation for $10 \mathrm{~min}$ at $10,000 \times g$ and $4^{\circ} \mathrm{C}$ were kept frozen in PBS until use.

\section{Purification of recombinant glycoproteins from $\mathrm{CHO}$ cells}

The glycoprotein fragments sL1CHO, IgI-VICHO, and FN1-5CHO were purified from conditioned culture medium by immunoaffinity chromatography using columns containing immobilized monoclonal anti- 
A

Figure 1. Schematic presentation of the recombinant glycoprotein and protein fragments with reference to the structure of L1. L1 is shown in the middle with six immunoglobulin-like domains (open half-circles) and five fibronectin type III homologous repeats (open squares). The transmembrane and the intracellular domains are indicated by the curved tail. Horizontal arrows on the left side mark the restriction sites [numbers of base pairs are according to Moos et al. (1988)] used to produce different DNA fragments. $A$, Three protein fragments produced in $\mathrm{CHO}$ cells are shown: sL1CHO stands for the whole extracellular part of L1. IgI-VICHO and FN1 -5CHO comprise all immunoglobulin-like domains and fibronectin type III homologous repeats, respectively. $B$, Seven recombinant protein fragments produced in $E$. coli are shown: IgI-VIEco, IgI-IIEco, IgIII-IVEco, IgVVIEco, FN1-5Eco, FN1-2Eco, and FN3-5Eco.

body 324 or 555 . The columns were washed with $0.02 \mathrm{M}$ Tris $\cdot \mathrm{HCl}, 0.15$ $\mathrm{M} \mathrm{NaCl}, 1 \mathrm{~mm}$ EGTA, and $1 \mathrm{~mm}$ EDTA, pH 7.2. The bound proteins were eluted with $0.1 \mathrm{M}$ diethylamine $\cdot \mathrm{HCl}, 100 \mathrm{~mm} \mathrm{NaCl}, 1 \mathrm{~mm}$ EGTA, $1 \mathrm{mM}$ EDTA, pH 11.5, and the eluted fractions were immediately neutralized with $1 \mathrm{M}$ Tris $\cdot \mathrm{HCl}, \mathrm{pH} 6.8$. Protein-containing fractions were concentrated on Amicon YM30 membranes (Wallisellen, Switzerland) and dialyzed against PBS (Fig. $2 A$ ). The purity of IgI-VICHO was determined by visual inspection of silver-stained gels after SDS-PAGE. The yields of sL1CHO and FN1-5CHO were so small that the glycoproteins could only be detected by Western blot analysis using polyclonal antibodies, but not by silver staining.

\section{Purification of recombinant proteins from $\mathrm{E}$. coli cells}

Recombinant proteins obtained as inclusion bodies from $E$. coli were solubilized in $8 \mathrm{M}$ urea solutions containing $1 \mathrm{mM}$ dithioerythritol, in different buffers according to the calculated isoelectric point (IEP) of the recombinant protein. For the recombinant proteins IgI-IIEco (IEP 6.7), IgIII-IVEco (IEP 6.8), and FN 1-5Eco (IEP 6.7), the urea solution was buffered with $20 \mathrm{~mm}$ Tris. $\mathrm{HCl}$, pH 8.0; for IgI-VIEco (IEP 5.1), IgV-VIEco (IEP 4.8), and FN1-2Eco (IEP 5.0), with $20 \mathrm{~mm}$ histidine. $\mathrm{HCl}, \mathrm{pH}$ 5.5; and for FN3-5Eco (IEP 8.4), with 20 mM HEPES, pH 7.5. The recombinant proteins, with the exception of FN3-5Eco, were then purified by fast protein liquid chromatography (FPLC) on a Mono $Q$ column (Pharmacia, LKB, Uppsala, Sweden) by applying an $\mathrm{NaCl}$ gradient from 0 to $750 \mathrm{mM}$. FN3-5Eco was purified by FPLC on a Mono $\mathrm{S}$ column (Pharmacia, LKB, Uppsala, Sweden), also by applying an $\mathrm{NaCl}$ gradient from 0 to $750 \mathrm{~mm}$. Eluted fractions were analyzed by SDS-PAGE (12\%), and the fractions with the highest purity were combined and dialyzed for at least $36 \mathrm{hr}$ at $4^{\circ} \mathrm{C}$ against PBS, in the case of recombinant proteins IgI-IIEco, IgIII-IVFco, and FN 1-2Fco; against 20 mM Tris-HCl, $\mathrm{pH} 8.5$, in the case of IgI-VIEco, IgV-VIEco, FN1-5Eco; and against $20 \mathrm{~mm}$ acetic acid, pH 5.5, in the case of FN3-5Eco. This dialysis against different buffers ensured that the protein fragments remained in solution when they were later diluted in PBS to the final concentration used in the test systems. All proteins exhibited a purity of more than $90 \%$ as estimated by SDS-PAGE (Fig. $2 B$ ). In the case of IgI-VIEco, the protein was also used unpurified, after solubilization in urea and dialysis against $20 \mathrm{~mm}$ Tris $\mathrm{HCl}, \mathrm{pH} 8.5$. This fraction, named IgI-VIEco n.p. (n.p. = not purified), contained approximately $30 \%$ recombinant protein, as estimated by SDS-PAGE.

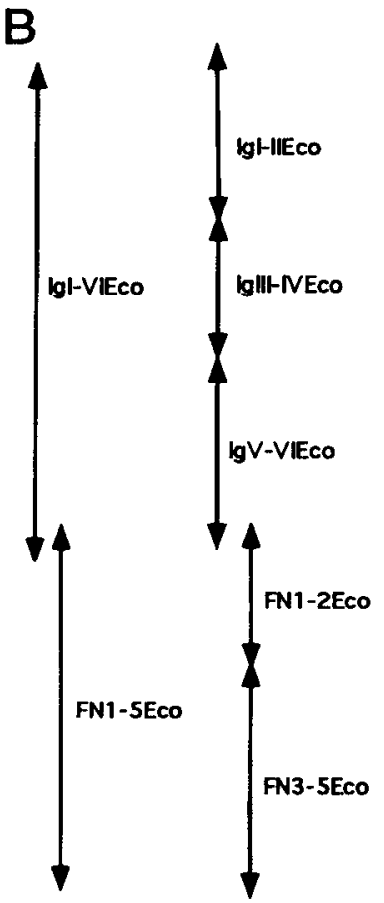

\section{Determination of neurite length}

Diethylether-cleaned glass coverslips $(1.4 \mathrm{~cm}$ in diameter) were coated overnight at $4^{\circ} \mathrm{C}$ with poly-L-lysine $(200 \mu \mathrm{g} / \mathrm{ml}$ in distilled water) and washed three times with distilled water. Stock solutions of proteins or glycoproteins were diluted in PBS and incubated on the coverslips overnight at $37^{\circ} \mathrm{C}$. The coating efficiency for the different glycoprotein and protein fragments, estimated as described in Analytical procedures, was similar for the protein fragments, since equal concentrations of the coating solutions, measured by the method of Bradford (1976) using Coomassie blue as a detection reagent, resulted in equal $\mathrm{OD}_{595}$ of adsorbed material. After washing the coverslips 10 times with basal medium Eagle's and twice with serum-free neuron culture medium (Fischer, 1982), purified small neurons from 6-7-d-old ICR mouse cerebella were seeded onto the coverslips $\left(10^{5}\right.$ cells in $100 \mu \mathrm{l}$ of neuron culture medium per coverslip). The small cerebellar neurons were obtained by sedimenting trypsinized cerebellar cells through a Percoll gradient (Keilhauer et al., 1985). The resulting neurons reexpressed $\mathrm{L} 1$ at their surface already after $1 \mathrm{hr}$ of incubation at $37^{\circ} \mathrm{C}$, as determined by indirect immunofluorescence with a polyclonal antibody directed against the recombinant protein fragment IgI-VICHO (not shown). After incubation at $37^{\circ} \mathrm{C}$ for $3 \mathrm{hr}$, the coverslips were immersed in $2 \mathrm{ml}$ of fresh medium in petri dishes $\left(35 \mathrm{~mm}\right.$ in diameter) and maintained at $37^{\circ} \mathrm{C}$ for additional $21 \mathrm{hr}$. The cells were then fixed for $1 \mathrm{hr}$ by adding 100 $\mu 1$ of $25 \%$ glutardialdehyde solution and stained with crystal violet $(0.5 \%$ crystal violet in $10 \%$ ethanol, $3 \%$ formaldehyde, $0.15 \mathrm{M} \mathrm{NaCl}$ ) for 10 min at room temperature. Antibody inhibition experiments were carried out by including antibodies at concentrations of $61 \mu \mathrm{g} / \mathrm{ml} \mathrm{(324)} \mathrm{or} 360$ $\mu \mathrm{g} / \mathrm{ml}(557 . \mathrm{B} 6)$ in neuron culture medium at the time of flooding the coverslips.

Crystal violet-stained cultures were analyzed by evaluating the lengths of individual neurites, using an Ai Tectron image analysis system (viDs Iv software, Bestobell Mobrey, Düsseldorf, Germany). Only neurites that did not contact other cells or neurites and had a length of at least one cell diameter were measured (Lemmon et al., 1989). For each experimental value, at least two independent experiments were performed in duplicate and more than 120 neurites (30 neurites/coverslip) were measured for each experimental value. For each substrate, more than two different preparations were used with similar results. Values for neurite outgrowth on different substrates are given as absolute increase in neurite length over the length obtained on poly-L-lysine alone $(29 \pm$ 
A

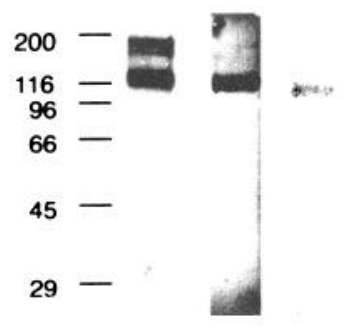

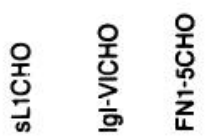

$\mathbf{B}$

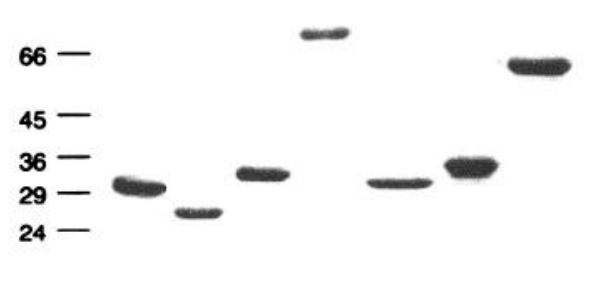

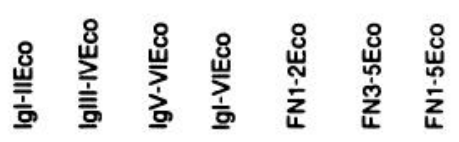

Figure 2. Biochemical characterization of recombinant $\mathrm{L} 1$ glycoprotein and protein fragments. $A$, SDS-PAGE and subsequent Western blot of protein fragments expressed in $\mathrm{CHO}$ cells (for abbreviations, see Fig. 1 caption). After electrophoresis, proteins were blotted onto nitrocellulose and incubated with immunoaffinity-purified polyclonal antibody against $\mathrm{Ll}(50 \mu \mathrm{g} / \mathrm{ml})$. The antibody binding was visualized by the enzymatic activity of alkaline phosphatase conjugated to an anti-rabbit IgG. The upper band of sL1CHO is a double band of 160 and $180 \mathrm{kDa}$. $B$, Characterization of purified protein fragments from $E$. coli by SDS-PAGE under reducing conditions (for abbreviations, see Fig. 1 caption). Proteins were visualized by staining with Coomassie blue. Molecular weight markers are indicated in kilodaltons at the left margins.
$3 \mu \mathrm{m}$ per cell). For independent experimental values, first the KruskalWallis and then the Mann-Whitney $U$ rank test, and for dependent values (antibody inhibition experiments) first the Friedman and then the Wilcoxon test, were used to determine the significance of differences in values, with $P<0.05$ and $P<0.01$ being considered significant and highly significant, respectively.

\section{Cell-to-substratum adhesion test}

On nitrocellulose. Bacteriological petri dishes (35 $\mathrm{mm}$ in diameter) were coated with nitrocellulose (BA85, Schleicher and Schuell, Dassel, Germany) dissolved in methanol according to Lagenaur and Lemmon (1987). Glycoprotein and protein fragments were diluted in PBS and spotted onto the nitrocellulose. The spots were not allowed to dry and, after incubating for $15 \mathrm{~min}$, excess solution was removed and the dishes were blocked for 30-60 min with a solution containing 5\% BSA in PBS, all at room temperature. Single cell suspensions of small cerebellar neurons were prepared (see Determinations of neurite length, above) and seeded into the petri dishes $\left(10^{6}\right.$ cells in $2 \mathrm{ml}$ of neuron culture medium per dish). After incubation at $37^{\circ} \mathrm{C}$ for $3 \mathrm{hr}$, the dishes were shaken at 150 $\mathrm{rpm}$ on a rotary minishaker (Alfred Kührer, Basel, Switzerland) for 2 $\mathrm{min}$ at room temperature. The cells were then fixed by adding $100 \mu \mathrm{l}$ of $25 \%$ of glutardialdehyde for $30 \mathrm{~min}$. The dishes were washed three times with distilled water to remove nonadherent cells and examined by phase-contrast microscopy. Numbers of adherent cells from four randomly chosen areas were determined with the help of an image processing system (IBAS, Kontron, Zürich, Switzerland). For any substrate, more than two different preparations were tested, with essentially identical results. In all figures, values for adhesion on different substrates are given as the percentage of cells bound to poly-L-lysine minus the unspecifically bound cells on blocked nitrocellulose. Raw data from at least four independent experiments were analyzed for statistical significance using hierarchical ANOVA and then the Newman-Keuls test, with $P<0.05$ and $P<0.01$ being considered significant or highly significant, respectively.

On bacteriological plastic. Ninety-six well bacteriological plates (269620A, Nunc, Denmark) were coated with glycoprotein and protein fragments at different concentrations from 0.5 to $30 \mu \mathrm{g} / \mathrm{ml}$ for $3 \mathrm{hr}$ at $37^{\circ} \mathrm{C}$ in PBS. The coating efficiency for the different glycoprotein and protein fragments, estimated as described in Analytical procedures, was similar for the protein fragments, since equal concentrations of coating solution, measured by the method of Bradford (1976) using Coomassie blue as a detection reagent, resulted in equal $\mathrm{OD}_{595}$ of adsorbed material. After blocking unsaturated binding sites with 5\% BSA in PBS for 30 min at room temperature, single cell suspensions of small cerebellar neurons were seeded in $100 \mu \mathrm{l}$ of neuron culture medium at a density of $10^{5}$ neurons per well. After $3 \mathrm{hr}$ at $37^{\circ} \mathrm{C}$ in a $\mathrm{CO}_{2}$ incubator, the cells were fixed by adding $5 \mu \mathrm{l}$ of $25 \%$ glutardialdehyde solution in $\mathrm{H}_{2} \mathrm{O}$ and incubated for at least $30 \mathrm{~min}$ at room temperature. Plates were then washed once with PBS and the cells were stained with crystal violet (see Determination of neurite length, above) for $10 \mathrm{~min}$ at room temperature.
After washing the plates with distilled water, bound crystal violet was solubilized by incubating first for 10 min with $20 \mu$ of $10 \%$ SDS in $\mathrm{H}_{2} \mathrm{O}$ and adding afterward $50 \mu \mathrm{l}$ of $70 \%$ ethanol for $30 \mathrm{~min}$ at room temperature. The optical density of the crystal violet solution was determined at $595 \mathrm{~nm}\left(\mathrm{OD}_{595}\right)$ using an ELISA reader. Cell adhesion was expressed as the $\mathrm{OD}_{595}$ value obtained on a given substrate, minus the background value obtained on blocked plastic. For comparison, the values observed on different substrates were expressed as the percentage of the value observed on poly-L-lysine. The data from at least three independent experiments carried out in triplicates were analyzed for statistical significance as described in the previous paragraph.

\section{Results}

To study the involvement of different extracellular domains of the neural cell adhesion molecule $\mathrm{Ll}$ of the mouse in neurite outgrowth and cell body adhesion, fragments of the molecule corresponding to the different structural domains were produced as recombinant proteins and glycoproteins in a prokaryotic and a eukaryotic expression system, respectively. In the prokaryotic expression system, $E$. coli cells, transformed with the pET expression vector (Studier et al., 1990), express nonglycosylated peptides whose disulfide bridges might not be correctly located. In the eukaryotic expression system (Bebbington, 1991), secreted soluble molecules can be expected to have correctly folded disulfide bridges and should be glycosylated, but the glycosylation pattern obtained in $\mathrm{CHO}$ cells may be different from that in the nervous system.

\section{Recombinant glycoprotein fragments of $\mathrm{LI}$ expressed in $\mathrm{CHO}$ cells}

Three glycoprotein fragments of $\mathrm{Ll}$ (sL1CHO, IgI-VICHO, FN1$5 \mathrm{CHO}$; see Fig. $1 A$ ) secreted by stably transfected $\mathrm{CHO}$ cell clones were purified by immunoaffinity chromatography from conditioned culture medium using monoclonal antibodies reactive with epitopes expressed in the individual fragments. Preparations of IgI-VICHO were at least $98 \%$ pure (not shown). The purity of sL1CHO and FN1-5CHO could not be ascertained, since these preparations gave no bands in silver-stained gels. In Western blots using polyclonal $\mathrm{Ll}$ antibodies, the purified molecules showed, for SL1CHO, three bands of 180,160 , and 120 $\mathrm{kDa}$ (calculated 120.8 kDa); for IgI-VICHO, one band at 106 $\mathrm{kDa}$ (calculated $68.4 \mathrm{kDa}$ ); and for FN1-5CHO, one band at 

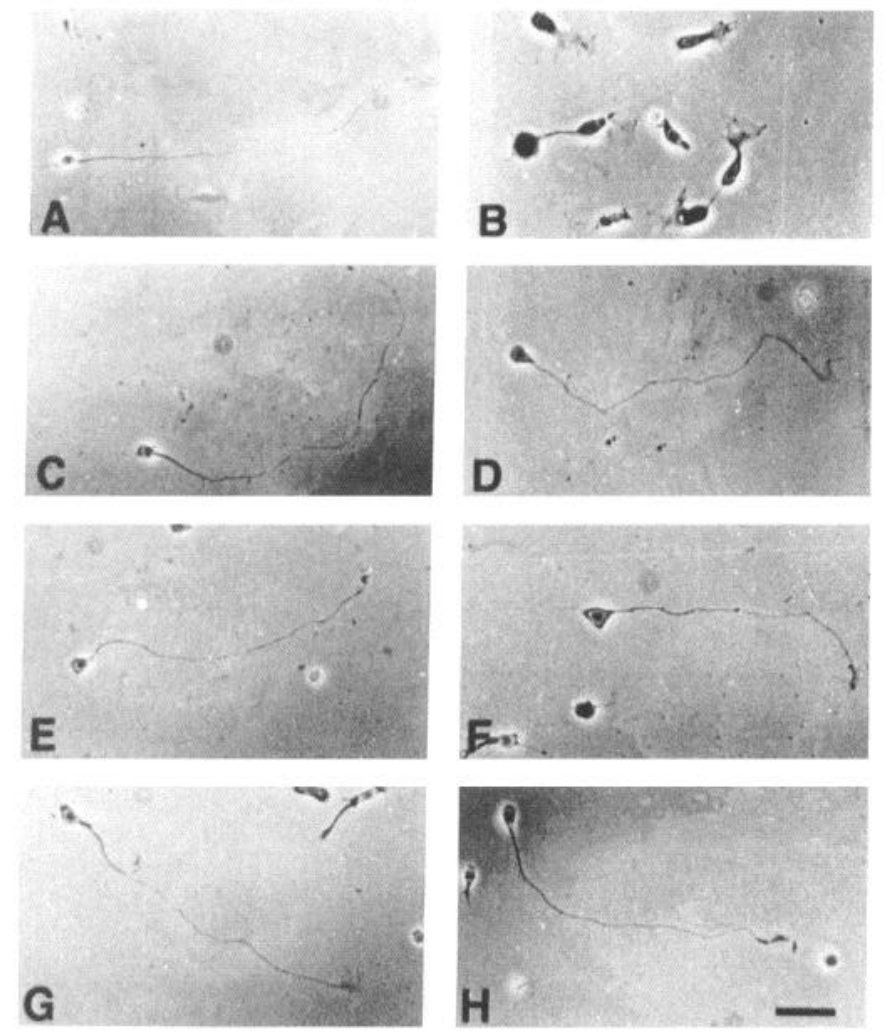

Figure 3. Neurite outgrowth on substrate-coated laminin, brain L1, sL1CHO, IgI-VICHO, IgI-VIEco, FN1-5CHO, and FN1-5Eco. Small cerebellar neurons were plated onto poly-L-lysine-treated glass coverslips $(B)$ coated overnight with laminin $(A), \mathrm{Ll}(C), \mathrm{sL1CHO}(D), \mathrm{IgI}-$ VICHO $(E)$, IgI-VIEco $(F)$, FN1-5CHO $(G)$, and FN1-5Eco $(H)$. Photomicrographs of cells after $24 \mathrm{hr}$ in culture are shown. Scale bar, $15 \mu \mathrm{m}$ (for $A-H$ ).

$100 \mathrm{kDa}$ (calculated $54.8 \mathrm{kDa}$ ) (Fig. $2 A$ ). The two lower bands of sL1CHO may be cleavage products, similar to those described for brain L1 (Sadoul et al., 1988). The differences between the calculated molecular weights of the protein backbone and the observed molecular weights of the glycoproteins are most likely due to glycosylation, since 22 putative glycosylation sites have been postulated for L1 (Moos et al., 1988). Typical yields of immunoaffinity-purified glycoprotein fragment IgI-VICHO was $6 \mathrm{mg}$ per liter of conditioned medium. For sL1CHO and FN1$5 \mathrm{CHO}$, yields were too small to measure protein concentrations.

\section{Recombinant protein fragments of L1 expressed in E. coli}

All protein fragments expressed in $E$. coli (Fig. $1 B$ ) were collected as inclusion bodies that were solubilized in $8 \mathrm{M}$ urea under reducing conditions and purified by ion-exchange chromatography using FPLC. In a single step, each protein fragment could be purified to at least $90 \%$ (Fig. $2 B$ ). The estimated molecular weights of purified protein fragments (Fig. $2 B$ ) are, for IgI-IIEco, $29 \mathrm{kDa}$ (calculated $26.6 \mathrm{kDa}$ ); for IgIII-IVEco, $25 \mathrm{kDa}$ (calculated $25 \mathrm{kDa}$ ); for IgV-VIEco, $33 \mathrm{kDa}$ (calculated $30 \mathrm{kDa}$ ); for IgI-VIEco, $75 \mathrm{kDa}$ (calculated $73 \mathrm{kDa}$ ); for FN1-2Eco, $30 \mathrm{kDa}$ (calculated $23.4 \mathrm{kDa}$ ); for FN3-5Eco, $34 \mathrm{kDa}$ (calculated 30 $\mathrm{kDa}$ ); and for FN1-5Eco, $58 \mathrm{kDa}$ (calculated $53.7 \mathrm{kDa}$ ), as estimated by SDS-PAGE under reducing conditions. The reason for the slight discrepancy between observed and calculated molecular weights is not known, since all expression constructs were confirmed to contain the correct nucleotide sequences. After chromatographic purification, protein fragments were refolded by extensive dialysis against appropriate buffers, the compositions of which were chosen according to the calculated IEP of each fragment. After dialysis, the protein fragments containing two immunoglobulin-like domains gave up to three bands by SDS-PAGE under nonreducing conditions and the protein fragment containing all six immunoglobulin-like domains (IgI-VIEco) gave more than 10 bands (not shown), as would be expected if several conformations were present due to different formation of disulfide bridges. Protein fragments containing fibronectin type III homologous repeats showed only one band by SDSPAGE under nonreducing conditions (not shown). Refolding of protein fragments by a more sophisticated protocol that had previously been demonstrated to lead to antigen binding activity of $\mathrm{F}_{\mathrm{ab}}$ fragments expressed in $E$. coli (Buchner and Rudolph, 1991) exhibited the same migratory properties by SDS-PAGE under nonreducing conditions and the same specific activity in the two functional test systems (not shown) as those renatured as described above. Typical yields of purified recombinant protein fragments were between 3 and $5 \mathrm{mg}$ per liter of bacterial culture.

\section{Functional tests}

Two assays were performed to investigate the functional roles of the different protein fragments of L1: neurite outgrowth and short-term adhesion. Since adhesion of cell bodies is a prerequisite for neurite outgrowth, we used an assay system in which neurite outgrowth could be distinguished from and measured independently of adhesion.

Neurite outgrowth of cerebellar neurons. To determine neurite outgrowth, glycoprotein or protein fragments were adsorbed onto poly-L-lysine-coated glass coverslips. Poly-L-lysine was used to ensure good adhesion of cell bodies, and the number of adherent neurons was similar for each fragment regardless of their neurite outgrowth promoting activity. For all fragments, the effects described in the following section were titrated using 5$100 \mu \mathrm{g} / \mathrm{ml}$ protein in the coating solution. Maximal effects were observed at $0.08 \mu \mathrm{M}(10 \mu \mathrm{g} / \mathrm{ml})$ for brain L1 and IgI-VICHO, $0.8 \mu \mathrm{M}$ for IgI-VIEco $(58.4 \mu \mathrm{g} / \mathrm{ml})$ and FN1-5Eco $(43 \mu \mathrm{g} / \mathrm{ml})$, and $1.6 \mu \mathrm{M}$ for IgI-IIEco $(42.7 \mu \mathrm{g} / \mathrm{ml})$, IgIII-IVEco $(40.1 \mu \mathrm{g} / \mathrm{ml})$, IgV-VIEco $(48 \mu \mathrm{g} / \mathrm{ml})$, FN1-2Eco $(37.6 \mu \mathrm{g} / \mathrm{ml})$, and FN3-5Eco $(48 \mu \mathrm{g} / \mathrm{ml})$. sL1CHO and FN1-5CHO could not be fully titrated, because of the low yield of the glycoproteins. However, the fragments were as active as the stock solution at a 1:2 dilution and less active at 1:4 and 1:8 dilutions.

In a first step, the neurite outgrowth-promoting ability of the extracellular part of $\mathrm{L} 1$ expressed in $\mathrm{CHO}$ cells (sL1CHO) and the protein fragments consisting of all six immunoglobulin-like domains and all fibronectin type III homologous repeats expressed both in CHO cells (IgI-VICHO and FN1-5CHO) and in $E$. coli (IgI-VIEco and FN1-5Eco) were compared to L1 isolated from adult mouse brain (brain L1) and laminin (Figs. 3, $4 A$ ). On laminin, a very good substrate for neurite outgrowth (Baron-van Evercooren et al., 1982; Manthorpe et al., 1983; Edgar et al., 1984), neurites reached an average length of 112 $\pm 4 \mu \mathrm{m}$ after $24 \mathrm{hr}$ in culture, which corresponds to an increase of $83 \mu \mathrm{m}$, or $285 \%$, compared to neurites grown on poly-L-lysine alone. Brain L1 and sL1CHO gave similar increases of $71 \mu \mathrm{m}$ (245\%) and $65 \mu \mathrm{m}(225 \%)$, respectively. IgI-VICHO and FN1$5 \mathrm{CHO}$ each gave an increase in mean neurite length of $42 \mu \mathrm{m}$ $(145 \%)$ and $30 \mu \mathrm{m}(100 \%)$. Interestingly, however, a mixture of the fragments IgI-VICHO and FN1-5CHO, at the same final 

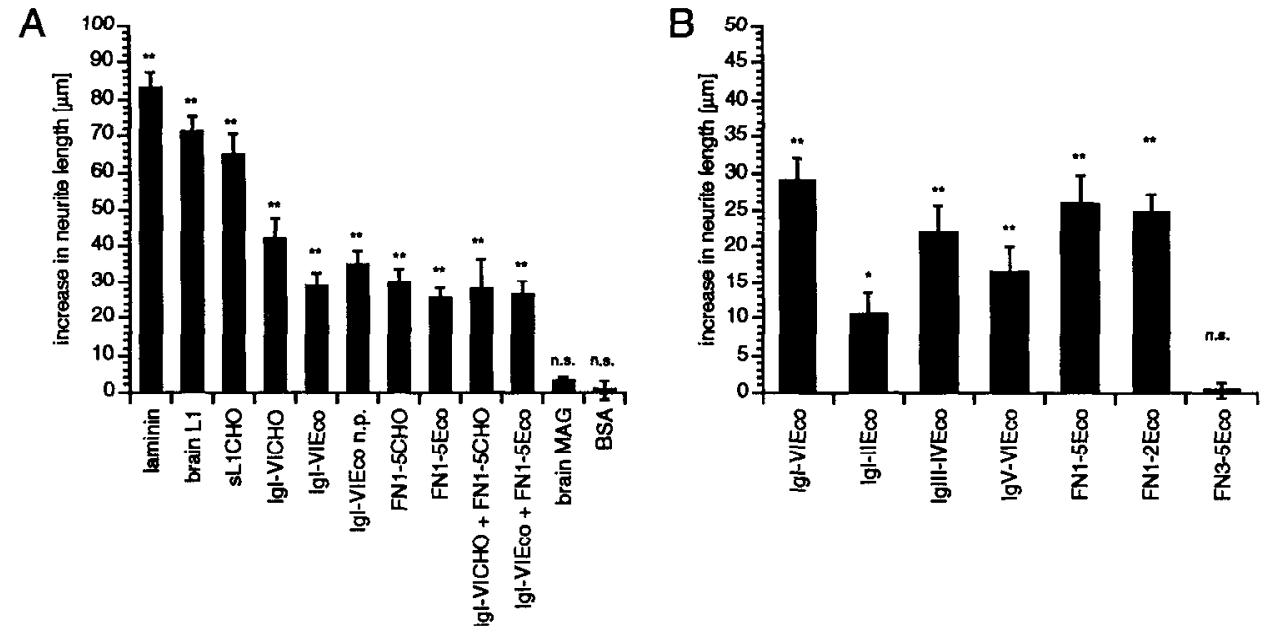

Figure 4. Determination of neurite length of small cerebellar neurons maintained on different substrates coated at protein concentrations displaying maximal effects: $A$, laminin $(0.02 \mu \mathrm{M})$, brain L1 $(0.08 \mu \mathrm{M})$, sL1CHO (undiluted stock solution), IgI-VICHO (0.08 $\mu \mathrm{M})$, IgI-VIEco (0.8 $\mu \mathrm{M})$, IgIVIEco n.p. (n.p., not purified; $0.8 \mu \mathrm{M}$ ), FN1-5CHO (1:2 diluted stock solution), FN1-5Eco $(0.8 \mu \mathrm{M})$, IgI-VICHO + FN1-5CHO (0.08 $\mu \mathrm{M}+1: 2$ diluted stock solution), IgI-VIEco + FN1-5Eco (0.8 $\mu \mathrm{M}$ each), brain MAG $(0.08 \mu \mathrm{M})$, and BSA (1.6 $\mu \mathrm{M}) ; B$, IgI-VIEco (0.8 $\mu \mathrm{M})$, IgI-IIEco (1.6 $\mu \mathrm{M})$, IgIII-IVEco $(1.6 \mu \mathrm{M})$, IgV-VIEco $(1.6 \mu \mathrm{M})$, FN1-5Eco $(0.8 \mu \mathrm{M})$, FN1-2Eco $(1.6 \mu \mathrm{M})$, and FN3-5Eco $(1.6 \mu \mathrm{M})$ adsorbed to poly-L-lysine-coated glass coverslips. Cells were incubated for $24 \mathrm{hr}$, fixed, and stained with crystal violet. Bars represent the absolute increase in mean neurite length per cell over the mean neurite length on poly-L-lysine alone $(29+3 \mu \mathrm{m}$ per cell) + SFM from at least two independent experiments carried out in duplicate. Bars marked by ${ }^{* *}, *$, or $n . s$. are highly significantly $(P<0.01)$, significantly $(P<0.05)$, or not significantly different from the control (poly-L-lysine alone as a substrate), respectively.

concentration as the individual fragments, was not more active than the individual fragments.

Both protein fragments expressed in $E$. coli, IgI-VIEco and FN1-5Eco, increased neurite outgrowth by approximately 29 $\mu \mathrm{m}(100 \%)$ and $26 \mu \mathrm{m}(90 \%)$ (Figs. 3, $4 A$ ), and the mixture of IgI-VIEco and FN 1-5Eco showed the same absolute increase in neurite length as each fragment alone. The specific activities of IgI-VIEco in unpurified and purified states showed no significant difference at the same relative protein concentrations, suggesting that the maximal activity of IgI-VIEco was not influenced by inhibitory contaminants. The observed effects were similar to those observed for glycoprotein fragments expressed in $\mathrm{CHO}$ cells, but the specific activity of the protein fragments expressed in $E$. coli was lower, since maximal effects required approximately 10 times higher concentrations of the bacterial proteins. The reasons for the lower specific activity of the $E$. coli fragments are not clear, but it is possible that only a fraction of the protein molecules are properly folded.

Neither BSA nor MAG, also a member of the immunoglobulin superfamily, increased neurite outgrowth significantly when compared to poly-L-lysine alone, indicating that stimulation of neurite outgrowth is not a consequence of merely coating any protein or glycoprotein onto poly-L-lysine.

These results show that the two main structural extracellular domains of $\mathrm{L1}$, the immunoglobulin-like domains and the fibronectin type III homologous repeats, are involved in and important for neurite outgrowth and contribute approximately equally to the functional activity of the whole molecule. However, full activity is only seen when the whole molecule is offered as a continuous protein backbone.

To determine the domains within the immunoglobulin-like domains or the fibronectin type III homologous repeats that are responsible for the neurite outgrowth promoting activity, we dissected the major domains into smaller protein fragments. These were expressed in $E$. coli only, since protein fragments expressed in $E$. coli coated at saturating concentrations are about as active as those expressed in $\mathrm{CHO}$ cells, and since expression in $E$. coli is less cumbersome. When the purified immunoglobulin-like domains I-II, III-IV, or V-VI were substrate coated onto poly-L-lysine, all fragments gave a weak, but statistically significant, increase in neurite outgrowth of $11-22 \mu \mathrm{m}(38-76 \%)$, when compared to poly-L-lysine alone (Fig. $4 B$ ). Each pair of immunoglobulin-like domains thus exhibited a smaller neurite outgrowth-promoting activity than IgI-VIEco. However, only the activity of IgI-IIEco or IgV-VIEco was significantly $(P<$ 0.05 for each) smaller when compared to IgI-VIEco. Of the fibronectin type III homologous repeats, only fibronectin type III homologous repeats 1-2 promoted neurite outgrowth as effectively as the fragment containing all fibronectin type III homologous repeats. Fibronectin type III homologous repeats $3-$ 5 were ineffective.

These results show that there are at least four distinct domains in the L1 molecule that promote neurite outgrowth. Two of these, IgIII-IV and FN1-2, are almost as active as the unfragmented immunoglobulin-like domains or fibronectin type III homologous repeats.

To verify further the involvement of substrate-coated L1 in the promotion of neurite outgrowth, neurite outgrowth was assayed in the presence of monoclonal $\mathrm{L} 1$ antibodies reacting with different domains of the molecule. Two monoclonal L1 antibodies, 324 and 557.B6, reacting with the immunoglobulin-like domains and the fibronectin type III homologous repeats, respectively, were tested for their ability to inhibit neurite outgrowth on brain $\mathrm{L} 1$ or protein fragments of L1. Both antibodies were able to inhibit neurite outgrowth on brain L1 by at least $80-90 \%$, when added $3 \mathrm{hr}$ after plating the cells on coverslips (Fig. 5A). Since the antibodies did not interfere with neurite outgrowth on laminin, cytotoxic effects can be excluded. When cells were maintained on substrate-coated sL1CHO, IgI-VI$\mathrm{CHO}$, or FN1-5CHO, both antibodies inhibited neurite out- 

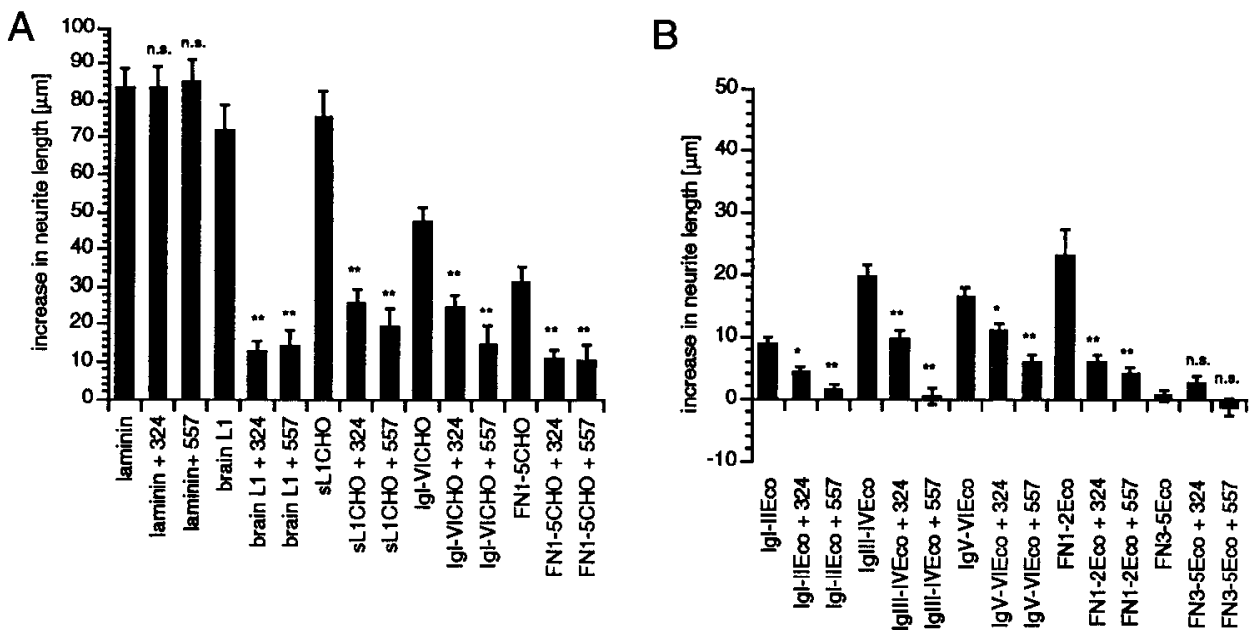

Figure 5. Effects of antibodies on neurite outgrowth from small cerebellar neurons maintained on different substrates coated at protein concentrations displaying maximal effects in the presence or absence of antibodies: $A$, laminin $(0.02 \mu \mathrm{M})$, brain $\mathrm{L} 1(0.08 \mu \mathrm{M})$, sL1CHO (undiluted stock solution), IgI-VICIIO $(0.08 \mu \mathrm{M})$, FN 1-5CIO (undiluted stock solution); $B$, IgI-IIEco $(1.6 \mu \mathrm{M})$, IgIII-IVEco $(1.6 \mu \mathrm{M})$, IgV-VIEco (1.6 $\mu \mathrm{M})$, FN1-2Eco $(1.6 \mu \mathrm{M})$, and FN3-5Eco $(1.6 \mu \mathrm{M})$ adsorbed to poly-L-lysine-coated glass coverslips. Cells were incubated for $24 \mathrm{hr}$, fixed, and stained with crystal violet. Three to four hours after seeding the cells, the coverslips were flooded in culture medium with or without antibodies $324 \mathrm{or} 557 . \mathrm{B} 6$ (61 $\mu \mathrm{g} /$ $\mathrm{ml}$ or $360 \mu \mathrm{g} / \mathrm{ml}$ for 324 or $557 . \mathrm{B} 6$, respectively). Bars represent the absolute increase in mean neurite length per cell over the mean neurite length on poly-L-lysine alone $(29 \pm 3 \mu \mathrm{m}$ per cell) \pm SEM from at least two independent experiments carried out in duplicate. Bars marked by **, *, or n.s. are highly significantly $(P<0.01)$, significantly $(P<0.05)$, or not significantly different, respectively, from the control situation, in which the cells were maintained on the same substrate without antibodies.

growth by $60-80 \%$. These results show that neurite outgrowth on brain $\mathrm{L} 1$ and $\mathrm{L} 1$ fragments are not caused by contaminants in the glycoprotein preparations. Furthermore, the reduction in neurite outgrowth on substrate-coated IgI-VICHO, in the presence of antibody 557.B6 (reacting with the fibronectin type III homologous repeats), can only be explained if $\mathrm{L} 1$ is blocked by the antibody at the cell surface. A similar situation is observed on substrate-coated FN1-5CHO in the presence of antibody 324. These observations suggest that $\mathrm{L} 1$ is a cell surfacc receptor for both protein fragments, although the inhibition of neurite outgrowth by the antibodies was not complete. Antibodies to TAG-1, a possible heterophilic ligand of L1 (Kuhn et al., 1991), did not inhibit neurite outgrowth on substrate-coated L1 (not shown).

We then tested whether the two antibodies could inhibit neurite outgrowth on the smaller protein fragments expressed in $E$. coli. Indeed, both antibodies were able to inhibit neurite outgrowth on all active L1 fragments (Fig. 5B). Preincubation of the cells with antibodies and removal of unbound antibody before the test was done also led to reduced neurite outgrowth, although the effect was slightly smaller than in the continued presence of the antibody (not shown).

These results confirm that the immunoglobulin-like domains and the fibronectin type III homologous repeats of $\mathrm{L} 1$ increase neurite outgrowth when offered as substratc and show that L1 functions as a specific cell surface receptor on cerebellar neurons for all fragments.

Cell-to-substratum adhesion test of cerebellar neurons. To determine short-term adhesion of cell bodies, glycoprotein or protein fragments were adsorbed onto nitrocellulose-coated plastic (Lagenaur and Lemmon, 1987). Unsaturated binding sites on the nitrocellulose were blocked with 5\% BSA in PBS, and cerebellar neurons were incubated on these substrates for $3 \mathrm{hr}$. As for the neurite outgrowth assay, titration curves were determined from 5 to $150 \mu \mathrm{g} / \mathrm{ml}$ protein in the coating solution, and maximal effects were observed at $0.8 \mu \mathrm{M}(100 \mu \mathrm{g} / \mathrm{ml})$ for brain L1, IgI-VIEco $(58.4 \mu \mathrm{g} / \mathrm{ml})$, and FN1-5Eco $(43 \mu \mathrm{g} / \mathrm{ml})$, and at $1.6 \mu \mathrm{M}$ for IgI-IIEco $(42.7 \mu \mathrm{g} / \mathrm{ml})$, IgIII-IVEco $(40.1 \mu \mathrm{g} / \mathrm{ml})$, IgVVIEco $(48 \mu \mathrm{g} / \mathrm{ml})$, FN1-2Eco $(37.8 \mu \mathrm{g} / \mathrm{ml})$, and FN3-5Eco (48 $\mu \mathrm{g} / \mathrm{ml}$ ) (Fig. 6A,B).

Under these conditions, only $26 \%$ of the neurons that attached to poly-L-lysine adhered to brain $\mathrm{Ll}$, while $83 \%$ adhered to laminin (Fig. $7 A$, solid bars). When protein fragments containing cither all immunoglobulin-like domains (IgI-VIEco) or fibronectin type III homologous repeats (FNI-5Eco) were used as substrates, $67 \%$ and $63 \%$, respectively, of the cells adhering to poly-L-lysine were attached. Unfortunately, the three glycoprotein fragments expressed in CHO cells could not be tested, because their concentrations in the stock solutions were too low to reach saturation.

MAG did nol increase adhesion of cerebellar neurons, compared to blocked nitrocellulose (see also Kadmon et al., 1990a).

These results show that the two main structural domains of L1 are involved not only in neurite outgrowth, but also in adhesion, and that these domains alone are significantly more active $(P<0.05)$ in adhesion than the whole molecule.

To determine the domains within the immunoglobulin-like domains and the fibronectin type III homologous repeats that are responsible for adhesion, we also tested the smaller protein fragments. Sixty percent of the cells adhered to the immunoglobulin-like domains I-II and V-VI, a value similar to all six immunoglobulin-like domains (Fig. $7 B$, solid bars), whereas only $33 \%$ adhered to immunoglobulin-like domains III-IV, a value comparable to brain L1. Cells adhered more strongly to the fibronectin type III homologous repeats 3-5 (86\%) and more weakly to fibronectin type III homologous repeats $1-2(37 \%)$ than to the protein fragment containing all five fibronectin type III homologous repeats $(63 \%)$.

These results show that there are at least five distinct L1 domains that are able to support short-term adhesion. Three of 

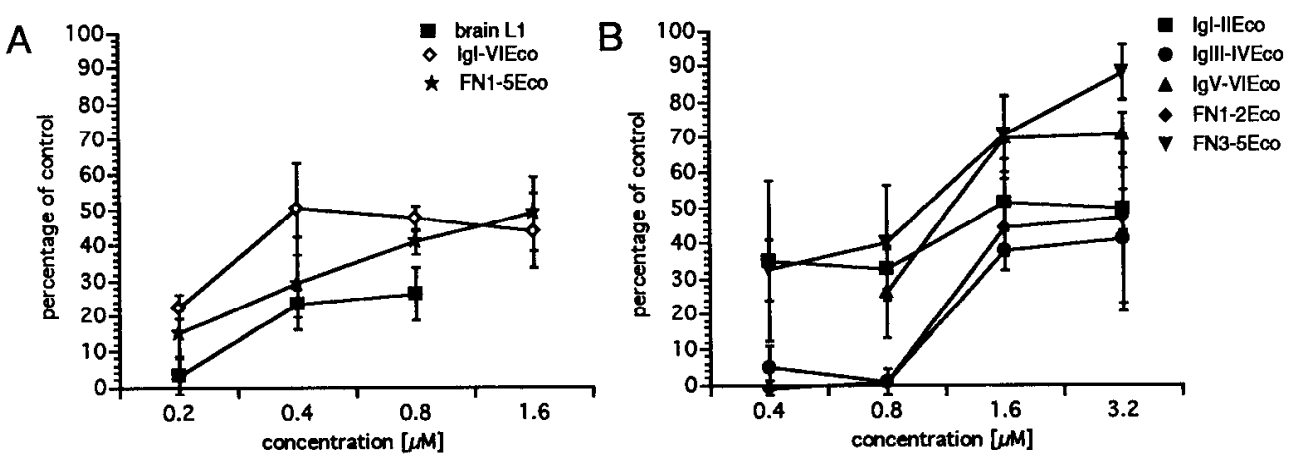

Figure 6. Determination of the adhesion of small cerebellar neurons to different substrates adsorbed to nitrocellulose-coated plastic as a function of protein concentration: $A$, brain Ll, IgIVIEco, and FN1-SEco; $B$, IgI-IIEco, IgIII-IVEco, IgV-VIEco, FN1-2Eco, and FN3-5Eco. Cells were maintained for 3 $\mathrm{hr}$, fixed, and counted. Values are given as percentages of cells bound to polyL-lysine $(=100 \%)$. Bars represent mean values $\pm \mathrm{SD}$ of one representative experiment. Another independent experiment gave similar results.

these, IgI-II, IgV-VI, and FN3-5, are better substrates than the whole L1 molecule.

To evaluate the influence of the substrate carrier in this assay, we compared nitrocellulose-coated plastic with uncoated plastic (Fig. $7 A, B$, open bars). No difference in the adhesion of cerebellar neurons to the $\mathrm{Ll}$ fragments was obscrved for the two carriers (Fig. $7 A, B$, solid and open bars), even though 10 times higher protein concentrations were necessary to obtain saturation for adhesion on nitrocellulose than on plastic. These results show that differences in adhesion to the different $\mathrm{Ll}$ fragments are not due to differences in adsorption to the carrier, since it is unlikely that the fragments adsorb in the same manner on different nonspecific substrate carrier.

To verify further the involvement of substrate-coated $\mathrm{L} 1$ in adhesion, assays were performed in the presence of antibodies 324 and 557.B6 (Fig. 8A,B). Both antibodies inhibited adhesion to brain L1 almost completely. Since the antibodies did not interfere with adhesion to laminin, cytotoxic effects of the antibodies could be excluded. When cells were allowed to adhere to the six immunoglobulin-like domains or five fibronectin type III homologous repeats, both antibodies also inhibited adhesion (Fig. $8 A$ ), as they did when adhesion to the smaller L1 fragments was measured (Fig. $8 B$ ). Since in each case at least one monoclonal antibody did not react with the substrate but with $\mathrm{L} 1$ at the cell surface of neurons, $\mathrm{Ll}$ has to be at least a part of the cell surface receptor for all active $\mathrm{L} 1$ domains.

The results of both functional assays are summarized in Table 1 .

\section{Discussion}

In an attempt to characterize the functionally important domains of the neural cell adhesion molecule L1, we analyzed the capacity of different fragments of $\mathrm{Ll}$ to promote neurite outgrowth and to mediate short-term adhesion of neuronal cell bodies. The use of individual L1 fragments in cell-to-substratum interactions was advantageous in isolating $\mathrm{Ll}$-mediated adhesion and neurite outgrowth from other recognition systems present on L1-expressing neural or transfected non-neural cells (see Lemmon et al., 1989; Kadmon et al., 1990a), since cell-to-cell binding studies have demonstrated that multiple adhesion systems contribute in an apparently redundant fashion to the cell surface interactions between cell types (Bixby et al., 1987; Neugebauer et al., 1988). To study neurite outgrowth and adhesion on substrate-coated proteins and protein fragments, we adopted the following strategy. First, we purified the recombinant proteins to a purity of at least $90 \%$ to minimize possible effects of contaminants. Second, in the neurite outgrowth assay, we used protein fragments derived from both prokaryotic and eukaryotic
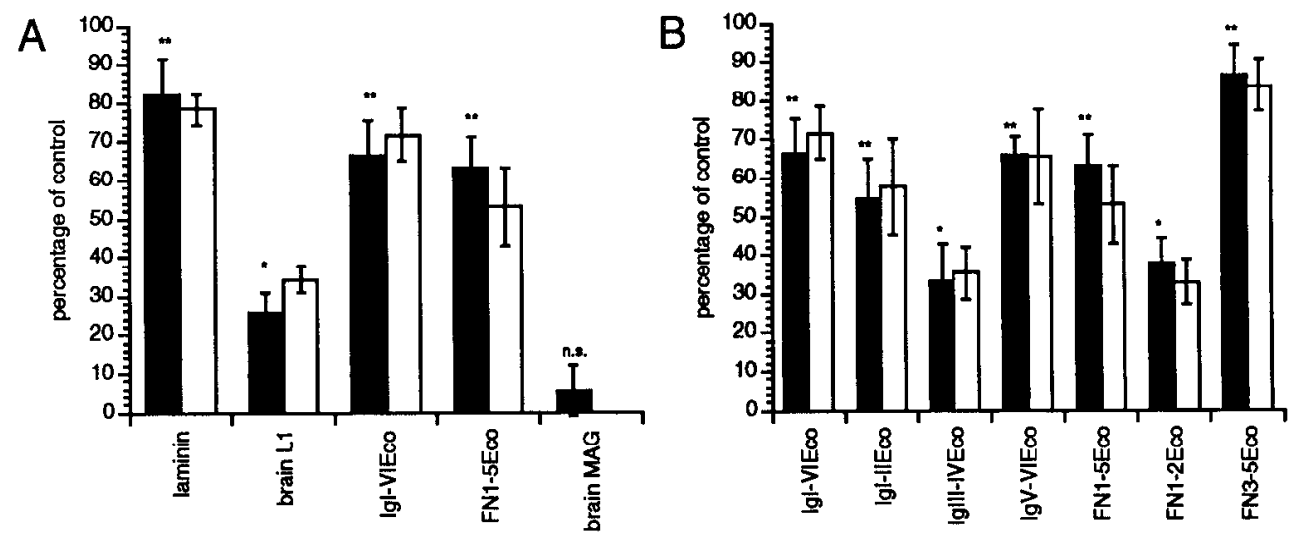

Figure 7. Determination of the adhesion of small cerebellar neurons to different substrates adsorbed to nitrocellulose-coated plastic (solid bars) or plastic alone (open bars) at protein concentrations displaying maximal effects: $A$, laminin $(0.08 \mu \mathrm{M})$, brain Ll $(0.8 \mu \mathrm{M})$, IgI-VIEco (1.6 $\mu \mathrm{M})$, FN15 Eco $(1.6 \mu \mathrm{M})$, and brain MAG $(2 \mu \mathrm{M})$ adsorbed to nitrocellulose-coated plastic or laminin $(0.02 \mu \mathrm{M})$; brain L1 $(0.08 \mu \mathrm{M})$, IgI-VIEco $(0.16 \mu \mathrm{M})$, and FN1-5Eco $(0.16 \mu \mathrm{M})$ adsorbed to plastic; $B$, IgI-VIEco $(1.6 \mu \mathrm{M})$, IgI-IIEco $(3.2 \mu \mathrm{M})$, IgIII-IVEco (3.2 $\mu \mathrm{M})$, IgV-VIEco (3.2 $\mu \mathrm{M})$, FN1-5Eco $(1.6 \mu \mathrm{M})$, FN1-2Eco $(3.2 \mu \mathrm{M})$, and FN3-5Eco $(3.2 \mu \mathrm{M})$ adsorbed to nitrocellulose-coated plastic or IgI-VIEco $(0.16 \mu \mathrm{M})$; IgI-IIEco $(0.32 \mu \mathrm{M})$, IgIII-IVEco (0.32 $\mu \mathrm{M})$, IgV-VIEco $(0.32 \mu \mathrm{M})$, FN1-5Eco $(0.16 \mu \mathrm{M})$, FN1-2Eco $(0.32 \mu \mathrm{M})$, and FN3-5Eco $(0.32 \mu \mathrm{M})$ adsorbed to plastic. Cells were incubated for 3 hr, fixed, and counted. Values are given as percentages of cells bound to poly-L-lysine $(=100 \%)$. Bars represent mean values \pm SEM from five (nitrocellulose) or three (plastic) independent experiments. Bars marked by ${ }^{* *}$, *, or $n$.s. are highly significantly $(P<0.01)$, significantly $(P<0.05)$, or not significantly different from the control (BSA alone as substrate), respectively. 

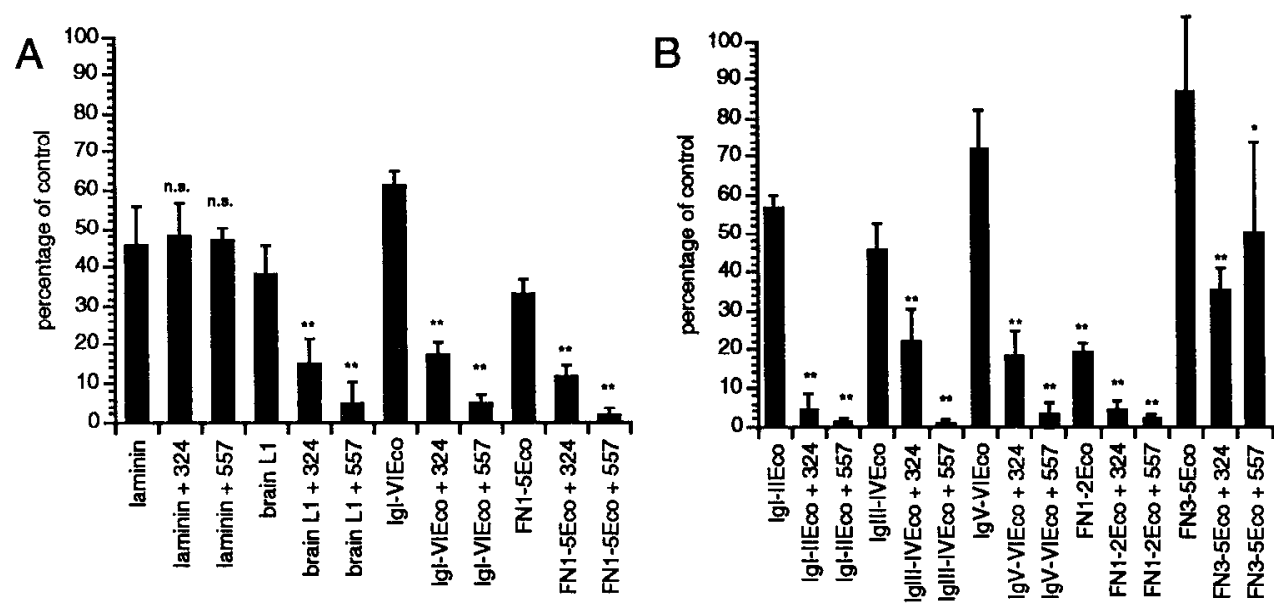

Figure 8. Determination of the adhesion of small cerebellar neurons to different substrates coated at protein concentrations displaying maximal effects in the presence or absence of antibodies: $A$, laminin $(0.02 \mu \mathrm{M})$, brain L1 $(0.8 \mu \mathrm{M})$, IgI-VIEco $(1.6 \mu \mathrm{M})$, FN1-5Eco $(1.6 \mu \mathrm{M}) ;(B)$ IgI-IIEco $(3.2$ $\mu \mathrm{M})$, IgIII-IVEco $(3.2 \mu \mathrm{M})$, IgV-VIEco $(3.2 \mu \mathrm{M})$, FN1-2Eco $(3.2 \mu \mathrm{M})$, and FN3-5Eco $(3.2 \mu \mathrm{M})$ adsorbed to nitrocellulose-coated plastic. Cells were incubated for $3 \mathrm{hr}$ with or without antibodies 324 or $557 . \mathrm{B} 6(0.3 \mathrm{mg} / \mathrm{ml}$ or $1.8 \mathrm{mg} / \mathrm{ml}$ for 324 or 557. B6, respectively), fixed, and counted. Values are given as percentages of cells bound to poly-L-lysine $(=100 \%)$. Bars represent mean values $\pm \mathrm{SD}$ of one representative experiment out of three experiments. The percentage of cells adhering to laminin was lower here than in Figure $7 A$, since lower amounts of laminin were used for these experiments. Bars marked by ${ }^{* *}, *$, or $n . s$. are highly significantly $(P<0.01)$, significantly $(P<0.05)$, or not significantly different, respectively, from the control situation, in which the cells were maintained on the same substrate without antibodies.

expression systems to see possible difficulties arising from improper folding of bacterially expressed proteins. Third, inhibition tests with monoclonal L1 antibodies were performed to strengthen the $\mathrm{L} 1$ specificity of the observed effects. Fourth, all experiments were performed at the maximal activity level in saturating concentrations of substrate-coated $\mathrm{L} 1$ fragments with comparable molarity. Finally, experiments were carried out using at least two different preparations of all protein fragments, with similar results.

To distinguish adhesion of cell bodies from neurite outgrowth, we chose two different assay systems. Adhesion was tested by coating $\mathrm{L} 1$ fragments onto two substrates, nitrocellulose and plastic, since both have a broad capacity to adsorb proteins. For neurite outgrowth, we used an assay system in which neurite outgrowth could be analyzed independently of adhesion, in that proteins were adsorbed onto poly-L-lysine, since the latter was found to be the most potent substrate for adhesion. In these assay systems, we found that both immunoglobulin-like do-

Table 1. Summary of the effects of brain L1 and L1 glycoprotein or protein fragments on neuronal adhesion and neurite outgrowth

\begin{tabular}{lll} 
Substrate & Adhesion & $\begin{array}{l}\text { Neurite } \\
\text { outgrowth }\end{array}$ \\
\hline Brain L1 & + & +++ \\
IgI-VI & ++ & ++ \\
FN1-5 & ++ & ++ \\
IgI-II & ++ & + \\
IgIII-IV & + & ++ \\
IgV-VI & ++ & + \\
FN1-2 & + & ++ \\
FN3-5 & +++ & -
\end{tabular}

The functional activities of brain L1 and the eukaryotically and prokaryotically expressed recombinant glycoprotein or protein fragments as substrates for adhesion and neurite outgrowth are represented as - , no effect; + , small effect; ++ intermediate effect; +++ , strong effect. Strength of adhesion is rated in comparison to substrate-coated poly-L-lysine $(+++)$ and neurite outgrowth in comparison to laminin $(+++)$. mains and fibronectin type III homologous repeats are involved in neurite outgrowth and adhesion. Interestingly, we found that all fragments of $\mathrm{L} 1$ are potent substrates for adhesion and exhibited similar or greater specific activity than L1 from mouse brain. For neurite outgrowth, none of the tested protein fragments was as potent as L1, but immunoglobulin-like domains III-IV and fibronectin type III homologous repeats $1-2$ were quite active, more than immunoglobulin-like domains I-II and V-VI, whereas only fibronectin type III homologous repeats 35 were inactive. With respect to the maximal functional activity of different fragments, there appears to be some specialization of domains for either neurite outgrowth or adhesion, since fragments that are most active in adhesion show only weak activity in neurite outgrowth and vice versa. Our observations also indicate that major functions of $\mathrm{L} 1$ for adhesion and neurite outgrowth can be attributed to the protein backbone, since unglycosylated protein fragments produced in $E$. coli were active.

We could also show that $\mathrm{Ll}$ is always a receptor at the neuronal cell surface for the substrate-coated protein fragments, since monoclonal antibodies that recognize only the cellular receptor and not the substrate-coated fragment inhibited neurite outgrowth and adhesion on L1, but not on laminin It can be ruled out that the L1 antibodies influence the potential of cells to adhere or extend neurites by unspecific steric hindrance of unrelated receptors or by triggering second messenger systems (see von Bohlen und Halbach et al., 1992), since adhesion and neurite outgrowth on laminin were not affected by the antibodies. However, other, possibly heterophilic receptors in adhesion or neurite outgrowth cannot be excluded, since the $\mathrm{L} 1$ antibodies were not always completely inhibitory. Heterophilic, yet unidentified, ligands for L1 have previously been described (Werz and Schachner, 1988; Pollerberg et al., 1990). It has recently been demonstrated that axonin-1 is a heterophilic receptor for Ng-CAM (Kuhn et al., 1991). Therefore, polyclonal antibodies against TAG-1, the rat homolog of axonin-1, were tested for their capacity to inhibit neurite outgrowth on substrate-coated L1. Intcrestingly, these antibodies did not inhibit neurite outgrowth, in agreement with the finding of Kuhn and colleagues, 
who found no inhibition of neurite outgrowth by antibodies to axonin-1 on substrate-coated $\mathrm{Ng}$-Cam, the putative chicken homolog of L1. Nevertheless, our findings clearly show that L1 is always at least a part of the cellular receptor or receptor complex for $\mathrm{L} 1$, and add evidence to the model that $\mathrm{L} 1$ is a molecule interacting in a homophilic manner.

The observation that the protein fragments are better substrates for adhesion than the whole native molecule, but that for neurite outgrowth the whole molecule is better than the fragments, is surprising. Reasons for such a finding could be manifold. Since all protein fragments acted at least in part through cellular $\mathrm{L} 1$, it is unlikely that adhesion results from nonspecific cell binding to misfolded recombinant proteins. In such a case one would not expect $\mathrm{Ll}$ to be the receptor on the cell surface. Another explanation could be that brain $\mathrm{Ll}$ is partially denatured during the purification procedure and adhesion is therefore impaired. However, it is difficult to believe that the domains active in neurite outgrowth would be less affected. A more likely explanation that we favor is the possibility that cell attachment sites are more exposed in the fragments than in the whole molecule.

Given that many extracellular domains are involved in adhesion and neurite outgrowth in vitro, it is pertinent to ask now whether fragments of $\mathrm{L} 1$ could also have a functional relevance in vivo. Different protein fragments of $200,180,140,80$, and $50 \mathrm{kDa}$ are described in $\mathrm{L} 1$ preparations from adult brain (Faissner et al., 1985). As shown for Ll (Sadoul et al., 1988) and $\mathrm{Ng}$-CAM (Burgoon et al., 1991), such fragments derive from the same protein molecule and do not result from alternative splicing. Expression of sL1CHO in $\mathrm{CHO}$ cells yielded three fragments following purification, also suggesting that secreted $\mathrm{L} 1$ is cleaved at specific sites. It is not known whether these different forms of $\mathrm{L} 1$ are artifacts of the isolation procedure, or if they are generated naturally to subserve a particular functional role in vivo. Interestingly, our results show that only those domains located distally from the proteolytic site in the third fibronectin type III homologous repeat, which leads to the 140 $\mathrm{kDa}$ and $80 \mathrm{kDa}$ fragments (Moos et al., 1988), promoted neurite outgrowth. Domains lying C-terminally from this site (FN3-5) were not active in neurite outgrowth, but were best for adhesion. It is thus tempting to speculate that the proteolytic cleavage of $\mathrm{L} 1$ at this particular site may subserve a functional role in vivo, in which the $140 \mathrm{kDa}$ fragment plays a role in neurite outgrowth and the complementary $80 \mathrm{kDa}$ fragment functions as a receptor for adhesion. It is interesting in this context that Durbec et al. (1992) showed that the soluble form of the L1-like adhesion molecule F3 stimulated neurite outgrowth.

It appears worthwhile to compare the present results with a similar study on N-CAM (Frei et al., 1992). For N-CAM, the immunoglobulin-like domains I and II and the fibronectin type III homologous repeats 1 and 2 are the best substrates for cell body adhesion, although other domains also show a significant adhesive potential. All five immunoglobulin-like domains together and both fibronectin type III homologous repeats were most active in neurite outgrowth, while immunoglobulin-like domain I and fibronectin type III homologous repeat 1 were less active. In summary, protein fragments of N-CAM are sufficient for adhesion, but only longer stretches of covalently linked domains are as active as the whole molecule for neurite outgrowth. Furthermore, both types of domains, immunoglobulinlike and fibronectin type III homologous ones are involved in the two functions characterized. The study did not identify the cellular receptors for the different N-CAM fragments, so it is uncertain if the fragments are active in homophilic or heterophilic mechanisms. Thus, in both L1 and N-CAM, the fibronectin type III homologous repeats are more than an inert spacer that merely changes the distance from the cell surface of the immunoglobulin-like domains. Since our observations suggest that multiple domains are involved in homophilic interaction of $\mathrm{L} 1$, they are in contrast to results recently published on N-CAM (Rao et al., 1992) in which N-CAM was suggested to center its homophilic activity in one domain. Therefore, it seems likely that homophilic binding is mediated by different mechanisms.

Since N-CAM and L1 are members of a large family of molccules sharing immunoglobulin-like domains and fibronectin type III homologous repeats, it is tempting to consider whether the findings for N-CAM and Ll are also valid for other members. Is there a general rule that molecules that combine the feature of extracellular molecules (fibronectin type III homologous repeats) with that of cell surface receptors (immunoglobulin-like domains) engage more than one of these structural motifs in the same function? Studies on related adhesion molecules in the immune system, which belong to the immunoglobulin superfamily but have no fibronectin type III homologous repeats, have shown a high degree of specialization of different immunoglobulin-like domains for heterophilic receptors. Examples are the antigen binding sites of antibodies, the CD4 binding to gp1 20 of HIV and MHC II molecules (Fleury et al., 1991) or the binding of the different ligands to ICAM-1 (Staunton et al., 1990; Diamond et al., 1991; Berendt et al., 1992; Ockenhouse ct al., 1992). In contrast to L1 and N-CAM, there are always only one or two closely located domains involved in specific recognition. Future experiments on N-CAM, $\mathrm{L} 1$, and related molecules should reveal whether these phylogenetically older homophilically acting recognition molecules represent a particular principle of ligand-receptor binding in that multiple domains subserve the same or similar functions. It also remains to be seen whether these multiple interactions are essential for one and redundant for another function.

With the data presented in this study, it seems possible to postulate different models for the homophilic interaction of L1 at the molecular level. Such models have to take into account that many domains of $\mathrm{L} 1$ are involved in adhesion and neurite outgrowth in the context of a homophilic interaction. Possible models are shown in Figure 9. The first model suggests that the interacting molecules recognize each other at different sites by a "heterophilic" mechanism (Fig. 9A,B). Two possible examples for this model are presented in which one domain interacts with one (Fig. 9A) or more than one (Fig. $9 B$ ) domain in a "heterophilic" manner. Alternatively, domains could bind to each other in a "homophilic" manner (Fig. 9C); that is, each domain interacts with the same domain on the partner molecule. These models would not only explain the observations that many protein fragments are responsible for adhesion and neurite outgrowth, but also account for the fact that all antibodies used to perturb adhesion and neurite outgrowth inhibited these functions. It is therefore tempting to speculate that perturbation of one site of the $\mathrm{L} 1$ molecule is sufficient to prevent recognition completely. The finding that FN3-5 shows potent adhesive properties is compatible with the proposed models, if one assumes that FN3-5 only becomes active after proteolytic cleavage. Indeed, preliminary experiments probing the binding of different L1 fragments to each other showed that FN3-5 binds more strongly than FN1-5 to other domains of L1 (J. Holm, F. 
A

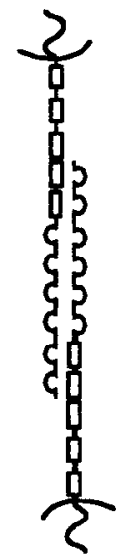

B

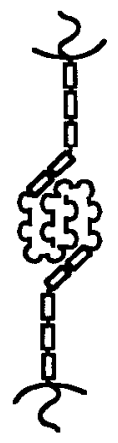

C

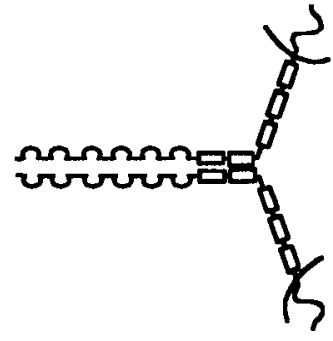

Figure 9. Different models for the homophilic interaction between L1 molecules on neighboring cells. The models presented could explain the observations in this study (for explanation of the symbols, see Fig. 1). The overall homophilic binding is mediated at the submolecular level by "heterophilic" (i.e., between different domains) $(A, B)$ or "homophilic" recognition (i.e., between identical domains) $(C)$.

Appel, and M. Schachner, unpublished observations). Further experiments will be necessary to determine which of these models is the most likely one.

\section{References}

Atashi JR, Klinz SG, Ingraham CA, Matten WT, Schachner M, Maness PF (1992) Neural cell adhesion molecules modulate tyrosine phosphorylation of tubulin in nerve growth cone membranes. Neuron $8: 831-842$.

Baron-Van Evercooren A, Kleinman HK, Ohno S, Marangos P, Schwartz JP, Dubois-Dalcq M (1982) Nerve growth factor, laminin, and fibronectin promote neurite outgrowth in human fetal sensory ganglia cultures. J Neurosci Res 8:179-193.

Barthels D, Santoni M-J, Wille W, Ruppert C, Chaix J-C, Hirsch M-R, Fontecilla-Camps JC, Goridis C(1987) Isolation and nucleotide sequence of mouse NCAM cDNA that codes for a $\mathbf{M}_{\mathrm{r}} 79000$ polypeptide without a membrane-spanning region. EMBO J 6:907-914.

Bebbington CR (1991) Expression of antibody genes in nonlymphoid mammalian cells. Methods 2:136-145.

Berendt AR, McDowall A, Craig AG, Bates PA, Sternberg MJE, Marsh K, Newbold CI, Hogg N (1992) The binding site on ICAM-1 for plasmodium falciparum-infected erythrocytes overlaps, but is distinct from, the LFA-1-binding site. Cell 68:71-81.

Bixby JL, Pratt RS, Lilien J, Reichardt LF (1987) Neurite outgrowth on muscle cell surfaces involves extracellular matrix receptors as well as $\mathrm{Ca}^{2+}$-dependent and -independent cell adhesion molecules. Proc Natl Acad Sci USA 84:2555-2559.

Bradford MM (1976) A rapid and sensitive method for quantitation of microgram quantities of protein utilizing the principle of proteindye binding. Anal Biochem 72:248-254.

Brümmendorf T, Wolff JM, Frank R, Rathjen FG (1989) Neural cell recognition molecule F11: homology with fibronectin type III and immunoglobulin type $C$ domains. Neuron 2:1351-1361.

Buchner J, Rudolph R (1991) Renaturation, purification and characterization of recombinant $\mathrm{F}_{\mathrm{ab}}$-fragments produced in Escherichia coli. Bio/Technology 9:157-162.

Burgoon MP, Grumet M, Mauro V, Edelman GM, Cunningham BA (1991) Structure of the chicken neuron-glia cell adhesion molecule, $\mathrm{Ng}-\mathrm{CAM}$ : origin of the polypeptides and relation to the Ig superfamily. J Cell Biol 112:1017-1029.

Chang S, Rathjen FG, Raper JA (1987) Extension of neurites on axons is impaired by antibodies against specific cell surface glycoproteins. J Cell Biol 104:355-362.

Chang S, Rathjen FG, Raper JA (1990) Neurite outgrowth promoting activity of G4 and its inhibition by monoclonal antibodies. J Neurosci Res 25:180-186.

Crocket MI, Bebbington CR, Yarranton GT (1990) High level expression of tissue inhibitor of metalloproteinases in chinese hamster ovary cells using glutamine synthetase gene amplification. Bio/Technology 8:662-667.

Cunningham BA, Hemperly JJ, Murray BA, Prediger EA, Brackenbury R, Edelman GM (1987) Neural cell adhesion molecule: structure, immunoglobulin-like domains, cell surface modulation, and alternative RNA splicing. Science 236:799-806.

Diamond MS, Staunton DE, Marlin SD, Springer TA (1991) Binding of the integrin Mac-1 (CD11b/CD18) to the third immunoglobulinlike domain of ICAM-1 (CD54) and its regulation by glycosylation. Cell 65:961-971.

Dodd J, Jessell TM (1988) Axon guidance and the patterning of neuronal projections in vertebrates. Science 242:692-699.

Drazba J, Lemmon V (1990) The role of cell adhesion molecules in neurite outgrowth on Müller cells. Dev Biol 138:82-93.

Durbec P, Gennarini G, Goridis C, Rougon G (1992) A soluble form of the F3 neuronal cell adhesion molecule promotes neurite outgrowth. J Cell Biol 117:877-887.

Edelman GM, Crossin KL (1991) Cell adhesion molecules: implications for a molecular histology. Annu Rev Biochem 60:155-190.

Edelman GM, Cunningham BA, Thiery JP (1990) Morphoregulatory molecules. Neurosciences Institute. New York: Wiley.

Edgar D, Timpl R, Thoenen H (1984) The heparin-binding domain of laminin is responsible for its effects on neurite outgrowth and neuronal survival. EMBO J 3:1463-1468.

Ey PL, Prowse SJ, Jenkin CR (1978) Isolation of pure IgG1, IgG2a and IgG2b immunoglobulins from mouse serum using protein A-Sepharose. Biochemistry 15:429-436.

Faissner A, Teplow DB, Kübler D, Keilhauer G, Kinzel V, Schachner M (1985) Biosynthesis and membrane topography of the neural cell adhesion molecule L1. EMBO J 4:3105-3113.

Fischer G (1982) Cultivation of mouse cerebellar cells in serum free, hormonally defined media: survival of neurons. Neurosci Lett 28 : 325-329.

Fleury S, Lamarre D, Meloche S, Ryu S-E, Cantin C, Hendrickson WA, Sekaly R-P (1991) Mutational analysis of the interaction between CD4 and class II MHC: class II antigens contact CD4 on a surface opposite the gp120-binding site. Cell 66:1037-1049.

Frei T, von Bohlen und Halbach F, Wille W, Schachner M (1992) Different extracellular domains of the neural cell adhesion molecule (NCAM) are involved in different functions. J Cell Biol 118:177-194.

Frelinger AL III, Rutishauser U (1986) Topography of NCAM structural and functional determinants. II. Placement of monoclonal antibody epitopes. J Cell Biol 103:1729-1737.

Furley AJ, Morton SB, Manalo D, Karagogeos D, Dodd J, Jessell TM (1990) The axonal glycoprotein TAG-1 is an immunoglobulin superfamily member with neurite outgrowth-promoting activity. Cell 61:157-170.

Gennarini G, Cibelli G, Rougon G, Mattei M-G, Goridis C (1989) The mouse neuronal cell surface protein F3: a phosphatidyl inositolanchored member of the immunoglobulin superfamily related to chicken contactin. J Cell Biol 109:775-788.

Grumet M (1992) Structure, expression, and function of Ng-CAM, a member of the immunoglobulin superfamily involved in neuronneuron and neuron-glia adhesion. J Neurosci Res 31:1-13.

Grumet M, Edelman GM (1988) Neuron-glia cell adhesion molecule interacts with neurons and astroglia via different binding mechanisms. J Cell Biol 106:487-503.

Grumet M, Mauro V, Burgoon MP, Edelman GM, Cunningham BA (1991) Structure of a new nervous system glycoprotein, Nr-CAM, and its relationship to subgroups of neural cell adhesion molecules. J Cell Biol 113:1399-1412.

Harlow E, Lane D (1988) Antibodies: a laboratory manual. Cold Spring Harbor, NY: Cold Spring Harbor Laboratory.

Harrelson AL, Goodman CS (1988) Growth cone guidance in insects: fasciclin II is a member of the immunoglobulin superfamily. Science 242:700-708.

Husmann K, Faissner A, Schachner M (1992) Tenascin promotes cerebellar granule cell migration and neurite outgrowth by different domains in the fibronectin type III repeats. J Cell Biol 116:14751486.

Kadmon G, Kowitz A, Altevogt P, Schachner M (1990a) The neural cell adhesion molecule N-CAM enhances L1-dependent cell-cell interactions. J Cell Biol 110:193-208. 
Kadmon G, Kowitz A, Altevogt P, Schachner M (1990b) Functional cooperation between the neural adhesion molecules $\mathrm{Ll}$ and $\mathrm{N}$-CAM is carbohydrate dependent. J Cell Biol 110:209-218.

Keilhauer G, Faissner A, Schachner M (1985) Differential inhibition of neurone-neurone, neurone-astrocyte and astrocyte-astrocyte adhesion by L1, L2 and N-CAM antibodies. Nature 316:728-730.

Kuhn TR, Stoeckli ET, Condrau MA, Rathjen FG, Sonderegger P (1991) Neurite outgrowth on immobilized axonin-1 is mediated by a heterophilic interaction with L1(G4). J Cell Biol 115:1113-1126.

Lacmmli UK (1970) Cleavage of structural proteins during the assembly of the head of bacteriophage T4. Nature 227:680-685.

Lagenaur C, Lemmon V (1987) An L1-like molecule, the 8D9 antigen, is a potent substrate for neurite extension. Proc Nall Acad Sci USA 84:7753-7757.

Lemmon V, Farr KL, Lagenaur C (1989) L1-mediated axon growth occurs via a homophilic binding mechanism. Neuron 2:1597-1603.

Manthorpe M, Engvall E, Ruoslahti E, Longo FM, Davis GE, Varon S (1983) Laminin promotes neuritic regeneration from cultured peripheral and central neurons. J Cell Biol 97:1882-1890.

Martini R, Schachner M (1986) Immunoelectron microscopic localization of neural cell adhesion molecules (I.1, N-CAM, and MAG) and their shared carbohydrate epitope and myelin basic protein in developing sciatic nerve. J Cell Biol 103:2439-2448.

Mayford M, Barzilai A, Keller F, Schacher S, Kandel ER (1992) Modulation of an N-CAM-related adhesion molecule with long-term synaptic plasticity in Aplysia. Science 256:638-644.

Miura M, Asou H, Kobayashi M, Uyemura K (1992) Functional expression of a full-length cDNA coding for rat neural cell adhesion molecule L1 mediates homophilic intercellular adhesion and migration of cerebellar neurons. J Biol Chem 267:10752-10758.

Moos M, Tacke R, Scherer H, Teplow D, Früh K, Schachner M (1988) Neural cell adhesion molecule $\mathrm{L} 1$ as a member of the immunoglobulin superfamily with binding domains similar to fibronectin. Nature 334: 701-703.

Neugebauer KM, Tomaselli KJ, Lilien J, Reichardt LF (1988) N-cadherin, NCAM, and integrins promote retinal neurite outgrowth on astrocytes in vitro. J Cell Biol 107:1177-1187.

Ockenhouse CF, Betageri R, Springer TA, Staunton DE (1992) Plasmodium falciparum-infected erythrocytes bind ICAM- 1 at a site distinct from LFA-1, Mac-1, and human rhinovirus. Cell 68:63-69.

Pollerberg GE, Davoust J, Schachner M (1990) Lateral Inobility of the cell adhesion molecule Ll within the surface membrane of morphologically undifferentiated and differentiated neuroblastoma cells. Eur J Neurosci 2:712-717.

Poltorak M, Sadoul R, Keilhauer G, Landa C, Fahrig T, Schachner M (1987) Myelin-associated glycoprotein, a member of the L2/HNK-1 family of neural cell adhesion molecules, is involved in neuron-oligodendrocyte and oligodendrocyte-oligodendrocyte interaction. J Cell Biol 105:1893-1899

Rao Y, Wu X-F, Gariepy J, Rutishauser U, Siu C-H (1992) Identification of a peptide sequence involved in homophilic binding in the ncural cell adhesion molecule NCAM. J Cell Biol 118:937-949.

Rathjen FG, Schachner M (1984) Immunocytological and biochemical characterization of a new neuronal cell surface component (L1 antigen) which is involved in cell adhesion. EMBO J 3:1-10.
Rosenberg AH, Lade BN, Chui D-S, Lin S-W, Dunn JJ, Studier FW (1987) Vectors for selective expression of cloned DNAs by T7 RNA polymerase. Gene 56:125-135.

Sadoul K, Sadoul R, Faissner A, Schachner M (1988) Biochemical characterization of different molecular forms of the neural cell adhesion molecule L1. J Neurochem 50:510-521.

Sadoul R, Kirchhoff F, Schachner M (1989) A protein kinase activity is associated with and specifically phosphorylates the neural cell adhesion molecule L1. J Neurochem 53:1471-1478.

Sambrook J, Fritsch EF, Maniatis T (1989) Molecular cloning: a laboratory manual. Cold Spring Harbor, NY: Cold Spring Harbor Laboratory.

Schachner M (1990) Functional implications of glial cell recognition molecules. In: Seminars in the neurosciences, Vol 2, Neurobiology of glia (Jessen KR, Mirsky R, eds), pp 497-507. New York: Saunders.

Schachner M (1991) Neural recognition molecules and their influence on cellular functions. In: The nerve growth cone (Letourneau PC, Kater SB, Macagno ER, eds), pp 237-254. New York: Raven.

Schuch U, Lohse MJ, Schachner M (1989) Neural cell adhesion molecules influence second messenger systems. Neuron 3:13-20.

Seilheimer B, Schachner M (1988) Studies of adhesion molecules mediating interactions between cells of peripheral nervous system indicate a major role for Ll in mediating sensory neuron growth on Schwann cells in culture. J Cell Biol 107:341-351.

Smith GM, Rutishauser U, Silver J, Miller RH (1990) Maturation of astrocytes in vitro alters the extent and molecular basis of neurite outgrowth. Dev Biol 138:377-390.

Staunton DE, Dustin ML, Erickson HP, Springer TA (1990) The arrangement of the immunoglobulin-like domains of ICAM-1 and the binding sites for LFA-1 and rhinovirus. Cell 61:243-254.

Studier FW, Moffatt BA (1986) Use of bacteriophage T7 RNA polymerase to direct selective high-level expression of cloned genes. J Mol Biol 189:113-130.

Studier FW, Rosenberg AH, Dunn JJ, Dubendorff JW (1990) Use of T7 polymerase to direct expression of cloned genes. Methods Enzymol 185:60-94.

von Bohlen und Halbach F, Taylor J, Schachner M (1992) The adhesion molecules L1 and N-CAM influence different second messenger systems in different neural cell types. Eur J Neurosci 4:896-909.

Werz W, Schachner M (1988) Adhesion of neural cells to extracellular matrix constituents. Involvement of glycosaminoglycans and cell adhesion molecules. Dev Brain Res 43:225-234.

Williams AF, Barclay AN (1988) The immunoglobulin superfamilydomains for cell surface recognition. Annu Rev Immunol 6:381-405.

Williams EJ, Doherty P, Turner G, Reid RA, Hemperly JJ, Walsh FS (1992) Calcium influx into neurons can solely account for cell contact-dependent neurite outgrowth stimulated by transfected L1. J Cell Biol 119:883-892.

Zuellig RA, Rader C, Schroeder A, Kalousek MB, von Bohlen und Halbach F, Osterwalder T, Inan C, Stoeckli ET, Affolter H-U, Fritz A, Hafen E, Sonderegger P (1992) The axonally secreted cell adhesion molecule, axonin-1. Eur J Biochem 204:453-463. 